\title{
The Hawk Men
}

By Richard Fyfe, Saskatchewan Falconry Association

additional 250 man-hours, 2,000 miles of driving and three days of tenting in pouring rain we were overjoyed to report nine new Prairie Falcon eyries and three new active Golden Eagle nests. Also all of our previously reported nesting Prairie Falcons were again nesting, making a total of 14 known active nests for this species.

In all, 93 nests were recorded this spring and summer, with the following numbers for each species: Golden Eagle, 4; Prairie Falcon, 14; Pigeon Hawk, 9; Sparrow Hawk, 6; Cooper's, 6; Sharp-shinned, 4; Ferruginous, 5; Swainson's, 3; Red-tailed 18; Great Horned Owl, 18; Longeared Owl, 2; Short-eared Owl, 1; Burrowing Owl, 3.

Unfortunately, only 18 immature birds were banded (Great Horned Owl, Prairie Falcon, Ferruginous Hawk), owing to lack of time, inexperience, and inclement weather. The nesting season was late and most of the nestlings too young to band when we arrived. Then late June rains made the earthen cliffs treacherous for climbing. However, we hope banding will become in the future one of our major undertakings, with a sufficient number banded to yield significant information, particularly about our native eagles and falcons.

Although it appears likely that there will soon be legislation at least partially protecting the birds of prey, we realize that legislation and actual protection are two quite different things. We cannot leave the whole matter to the government; we must make every effort individually to insure that rare species like the Prairie Falcon and Golden Eagle are protected. We can do this by persuading the residents of the areas where these birds nest of the importance of protecting them -through the press, public talks, and personal contacts with landowners. The landowner is the key figure, because the remote areas where falcons and eagles nest are virtually inaccessible except by roads through the farmsteads. Tris places the farmer or rancher in a unique position: he can screen all traffic into the rangeland. I am 
pleased to say that this past summer we were able to insure protection of one of the eagle eyries and two Prairie Falcon eyries in this way.

To help inform people of the desirability of protecting these birds, I should like to volunteer the services of the Falconry Club, with slides, movies and our trained birds. Everyone in the natural history societies can help by making personal contacts with the owners of property where nests are found.

Egg collectors and nest robbers are our greatest problem, and I think on a provincial scale this is a matter of concern to our Natural History Society second only to the shotgun. On several occasions Great Horned Owl, Red-tailed and Cooper's Hawk nests were robbed of all eggs and young. Some of these young birds appeared later as so-called pets which became problems in different communities. Although falconers are often blamed for these renegade birds, no group is more opposed to this practice. One bird alone resulted in no less than 26 phone calls and one personal complaint to me, simply because people felt it must be one of our birds. No bird about which there were complaints in the city of Regina was owned or trained by the Falconry Club. This was not because our birds did not go free, but because those birds which did go free could care for themselves and reverted to the wild almost immediately. One of our released Prairie Falcons was observed for almost a month hunting

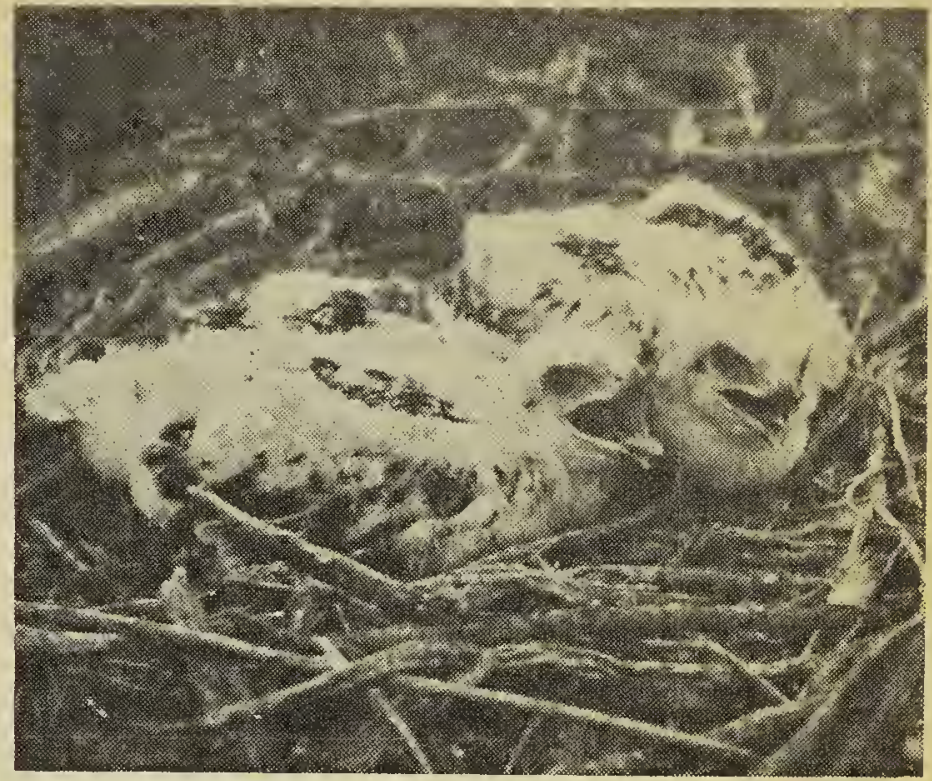

Photo by R. Fyfe.

Downy Ferruginous in a nest in the Big Muddy Valley.

less than two miles away, but it was very wild indeed.

Falconers deplore the keeping of large rawks and owls as pets because the people who take them seldom understand their needs. Usually the young are taken from the nest when they are very small and downy and appealing. Failing to get the right food, these birds suffer from nutritional deficiencies and develop a crippling form of rickets which renders them incapable of ever catching their own food. As they grow they develop such annoying habits as screaming, and they eat too much and simply outgrow their attractiveness. The next step is obvious - to release the birds. These freed birds have little chance for survival

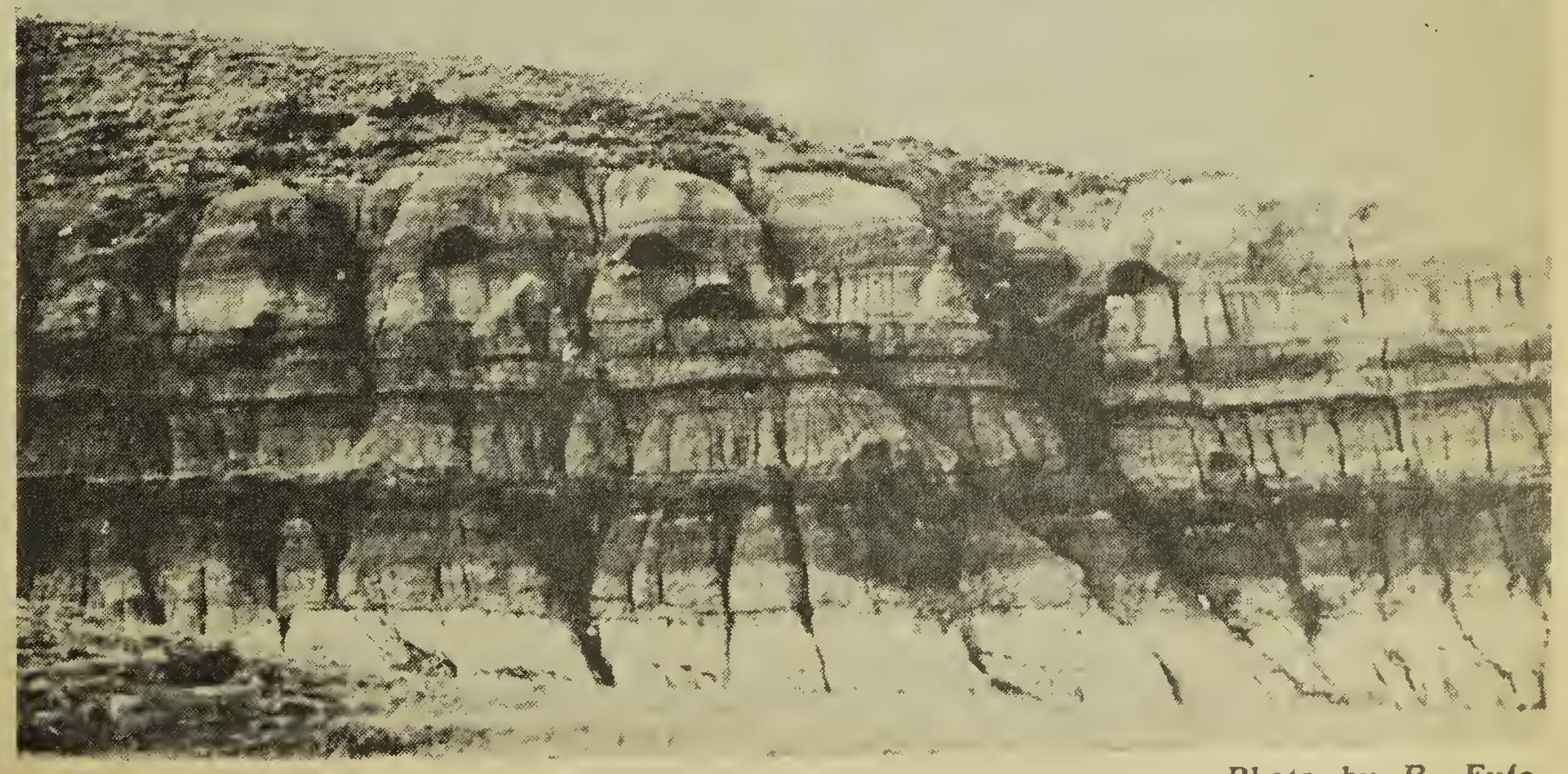

Nests of the Ferruginous Hawk on an eroded hillside in the Big Muddy Valley. 
except by relying on humans for food. Therefore they stay near humans until they die or are shot. At this stage Great Horned Owls and Red-tails can be extremely dangerous. You have only to think of their strength to imagine what might happen if the bird should inadvertently land on a small child or pick at something in his hand.

Not only are we as falconers very much aware of the undesirability of keeping hawks and owls as pets, we are doing our best to eliminate this practice through legislation. We feel that the taking of young birds should be rigidly controlled through a permit system similar to the present collecting permit system. This would ensure the establishing of definite regulations and the enforcing of them. In the meantime, every one of us can make a personal effort to see that others become aware of the need for protection of our native birds of prey.

\section{The Big Snow of October}

\section{By Frank Brazier, Regina}

On October 8, 1959, a low pressure area formed in the Pacific Ocean off the coast of British Columbia and moved eastwards. Ahead of it the temperature dropped to $18^{\circ} \mathrm{F}$ and by morning an incl: of snow lay on the ground. After the low had moved inland a series of low pressure systems formed in the same original area and likewise moved inland so that a train of low pressure systems was created. The first in the series reached Regina about 7 a.m. on October 9 and by mid-morning it had started to snow in earnest, the wind increasing to 25-30 m.p.h. By noon of the 12th, snow 10.4 inches deep was underfoot. The disturbance finally extended to Battleford and Prince Albert in the north, the nortr-ern tier of states on the south and well into Ontario in the east. Western Manitoba actually bore the brunt as the systems stalled on the Turtle Mountains with the result that it snowed almost continuously, 30 inches piling up. After the 9th the wind was not troublesome but the temperature averaged $20^{\circ} \mathrm{F}$ minimum and $26^{\circ} \mathrm{F}$ maximum for tre four days. These low temperatures iced much of the Wascana Creek system except for the open water caused by the Regina power plant's warm discharge, and the odd puddle here and there.

The power plant discharge kept half of the Wascana Marsh ice-free which was a boon to migrating waterfowl, and they piled in there in thousands to wait for better weather. Some stretches of Wascana Lake likewise did not freeze and these too were crowded. The tail-end of the migration of other birds found conditions miserable but manageable and I saw no evidence of suffering. Myrtle and Orange-crowned Warblers gleaned the trees as did the kinglets and, surprisingly enough, the juncos. Hermit Thrushes and Robins went to work on the berry crop while White-throated Sparrows pecked into hanging fruit for the seeds. Most of the trees and shrubs still held their foliage wrich sheltered much of the ground from deep snow and in the hedges and under shrubs Harris and White-crowned Sparrows searched assiduously. Tree Sparrows and juncos fell on to weed heads while Purple Finches took samaras. Oddly enough I saw a House Sparrow also sampling the winged seeds of Manitoba Maple.

In Rotary Park, Wascana Creek remained open here and there where tree water moved more quickly, and here Rusty Blackbirds and Grackles hung about in disconsolate groups; over one patch of open water a Kingfisher maintained a watch while a couple of Greater Yellowlegs and three Common Snipe moved from one pool to the other. At one of these a Sora searched the mud, retreating at my approach under a curtain of overhanging grass on the creek bank into an old muskrat burrow. It was tastefully arrayed in a pair of crystal gaiters which rad formed as the water in which it waded froze its legs. This rail stayed until October 20 and when last seen appeared perky and in good spirits. During the most miserable day, the windy, snowy, cold 9 th, I noticed the Kingfisher sheltering in a large drain from which: he would make sorties to what open water remained. 